\title{
Sources of variability in SERS spectra of bacteria: comprehensive analysis of interactions between selected bacteria and plasmonic nanostructures
}

\author{
Evelin Witkowska $^{1} \cdot$ Krzysztof Niciński $^{1} \cdot$ Dorota Korsak $^{2} \cdot$ Tomasz Szymborski $^{1} \cdot$ Agnieszka Kamińska $^{1}$
}

Received: 14 November 2018 / Revised: 17 December 2018 / Accepted: 14 January 2019 / Published online: 4 March 2019

(C) The Author(s) 2019

\begin{abstract}
The surface-enhanced Raman spectroscopy (SERS)-based analysis of bacteria suffers from the lack of a standard SERS detection protocol (type of substrates, excitation frequencies, and sampling methodologies) that could be employed throughout laboratories to produce repeatable and valuable spectral information. In this work, we have examined several factors influencing the spectrum and signal enhancement during SERS studies conducted on both Gram-negative and Gram-positive bacterial species: Escherichia coli and Bacillus subtilis, respectively. These factors can be grouped into those which are related to the structure and types of plasmonic systems used during SERS measurements and those that are associated with the culturing conditions, types of culture media, and method of biological sample preparation.
\end{abstract}

Keywords Surface-enhanced Raman spectroscopy (SERS) · Wire mesh · SERS platform $\cdot$ Escherichia coli $\cdot$ Bacillus subtilis

\section{Introduction}

Surface-enhanced Raman spectroscopy (SERS) spectroscopy is a technique based on the study of oscillations of molecules located on roughened metal surface. The amplification of the SERS signals occurs via the formation of charge transfer complex between the analyte and the SERS substrate, but mainly through the electromagnetic interaction of light with metal, which produces large amplifications of the laser field. The electromagnetic enhancement is connected with the presence of surface

Electronic supplementary material The online version of this article (https://doi.org/10.1007/s00216-019-01609-4) contains supplementary material, which is available to authorized users.

Evelin Witkowska ewitkowska@ichf.edu.pl

Agnieszka Kamińska akamin@ichf.edu.pl

1 Institute of Physical Chemistry, Polish Academy of Sciences, Kasprzaka 44/52, 01-224 Warsaw, Poland

2 Faculty of Biology, Department of Applied Microbiology, Institute of Microbiology, University of Warsaw, Miecznikowa 1, 02-096 Warsaw, Poland plasmons-coherent delocalized electron oscillations across the surface [1].

High selectivity, sensitivity, and the possibility to analyze a trace amount of substances are the main advantages proposed by SERS. In addition, there is no need to use expensive reagents and labels or to employ qualified personnel to carry out the experiment. The SERS spectrum of chemical compounds resembles the normal Raman spectrum (they are both the source of information about the structure of studied compounds). Unfortunately, in the case of biological samples, the background fluorescence often completely covers signals from the sample during normal Raman measurements and, therefore, it is very difficult to obtain pure Raman spectrum.

The power of SERS lies also in its ability to identify chemical species in a very fast way. It can be used to detect and identify pigments [2], poisons [3], narcotic substances [4-6], and materials of biological origin [7-10]. It is also applied in examination of single molecules $[11,12]$ and in identification of structures more complicated than chemical compounds, namely viruses [13, 14], fungi [15], cancer cells [16-18], and bacteria [19-21].

The topic of microorganism identification by SERS is hugely important from biological, biotechnological, and medical points of view. In these branches of science, the new methods of bacterial identification are extremely desired. This is due to the fact that currently used techniques, including polymerase chain reaction, biochemical tests, and 
immunochemical methods, despite their high accuracy, still cannot overcome the main factor which makes them imperfect-time consumption. The SERS technique may resolve this problem, as the single measurement can be done in only few seconds. For the abovementioned reasons, over the last years, the interest in SERS of bacteria is big. This is revealed by an increase in the number of scientific publications on this topic (see Electronic Supplementary Material (ESM) Fig. S1).

Despite the knowledge about the principles of SERS mechanism, the detailed information remains still unknown. The more complex the examined sample, the more it is difficult to determine the origin of the vibrations observed in the SERS spectrum. Therefore, spectral analysis of bacteria, which are composed of hundreds of different molecules, is a serious issue. SERS technique has also some restrictions. First, the analyte should be very pure as the contamination of the sample may result in additional bands in the spectrum. Moreover, the SERS effect is limited to $\sim 20 \AA$ from the surface of the metal substrate, so in the case of measurements of viable bacterial cells, the obtained signals may be assigned only to first few layers of the cell (cell wall, cell membrane, and molecules attached to them).

This work is the first step to standardize the conditions, which enable to obtain reproducible SERS spectra of particular bacteria. The factors influencing the spectrum and signal enhancement of selected bacterial species in SERS have been studied. They can be grouped into those which are related directly to the SERS platforms and measurement parameters and those which are associated with the cell cultivation process and method of sample preparation.

Not all SERS substrates are suitable for bacterial cell measurements. In some cases, spectra cannot be compared with each other, especially if they were obtained by using different SERS substrates covered with distinct SERS-active metals. Equally important for the results are measurement parameters: time of exposure to laser radiation, laser line, and laser power. It is important to verify the influence of the type of plasmonic structures on bacterial SERS spectra. Here, we show, for the first time, how the type of used SERS substrates (obtained in different production processes), the duration of cell cultivation, and additional treatment during sample preparation affect SERS spectra of bacteria. Moreover, during SERS measurements, we have used four different laser lines $(325 \mathrm{~nm}$, $514 \mathrm{~nm}, 633 \mathrm{~nm}$, and $785 \mathrm{~nm}$ ) and six laser power levels of the selected laser line. We have also checked the impact of SERS-active metal/alloy and the duration of the experiment on the SERS spectra of bacteria as silver nanoparticles (NPs)/ nanostructures are toxic to bacteria. This toxic effect is connected with generation of reactive oxygen species (ROS) upon exposure of cells to silver (Ag) NPs [22]. As the result, they may indirectly disrupt the function of cytoplasmic membrane, inactivate key enzymes, interact with nucleic acids, interfere with metabolic and respiratory processes, and cause death of the cell [23]. This, in turn, may lead to some changes in the quality of obtained SERS spectrum.

We present as well how the culture conditions may affect the structure and chemical composition of bacteria and, thus, their SERS spectra. Precisely, we show how the type of culture media and death of bacteria may affect their SERS signal intensity and quality. We have focused on two model bacterial species: Gram-negative Escherichia coli and Gram-positive Bacillus subtilis.

\section{Materials and methods}

\section{Bacterial species}

Two bacterial strains (E. coli $\mathrm{K} 12$ and B. subtilis 168) were obtained from the Department of Applied Microbiology, University of Warsaw, Poland.

\section{Culture conditions and sample preparation}

\section{Storage}

Cultures of E. coli and B. subtilis were maintained in Trypticase soy-yeast extract agar (TSYEA) (Oxoid, Basingstoke, Hampshire, UK) at $4{ }^{\circ} \mathrm{C}$ throughout the study period and stored at $-80{ }^{\circ} \mathrm{C}$ in brain heart infusion (BHI) broth supplemented with $20 \%$ glycerol.

\section{Culture media and conditions of bacterial cultivation}

The following culture media were purchased from Biocorp, Poland: Luria-Bertani (LB) agar medium, BHI agar, and Mannitol Egg Yolk Polymyxin (MEYP) agar for cultivation of B. subtilis and LB agar medium, BHI agar, Tryptone Bile X-Glucuronide (TBX) agar, and Chromogenic Coliform Agar (CCA) for cultivation of $E$. coli. All the plates were incubated at $37^{\circ} \mathrm{C}$ for $24 \mathrm{~h}$. Additionally, the plates with LB agar and E. coli or B. subtilis were cultured for $48 \mathrm{~h}$ and $72 \mathrm{~h}$ to check the influence of the culture duration on the SERS spectrum.

\section{Death of bacteria}

In order to cause death of bacterial cells, they were suspended in $70 \%$ ethanol, frozen in saline solution at $-80{ }^{\circ} \mathrm{C}$ for $24 \mathrm{~h}$, centrifuged $(13,150 \times g)$ for $10 \mathrm{~min}$, heated to $100^{\circ} \mathrm{C}$ in saline solution for $1 \mathrm{~h}$, and exposed to UV light for $1 \mathrm{~h}$.

\section{Sample preparation for SERS measurements}

For viable $E$. coli and B. subtilis cells, after $24 \mathrm{~h}$ (or $24 \mathrm{~h}, 48 \mathrm{~h}$, and $72 \mathrm{~h}$ in the case of bacteria cultured on LB agar medium), 
three single colonies were placed via a sterile plastic inoculating loop into $200 \mu \mathrm{L}$ of sterile $0.9 \% \mathrm{NaCl}$ solution, mixed, and centrifuged for $3 \mathrm{~min}$ at $1070 \times \mathrm{g}$. The centrifugation process in the saline solution was repeated three times to obtain a solution of clean bacterial cells. Purified bacteria were finally suspended in $10 \mu \mathrm{L}$ of sterile $0.9 \% \mathrm{NaCl}$ solution. The mixtures were next placed over the SERS substrates and measured after $\sim 5 \mathrm{~min}$ (or $5 \mathrm{~min}, 15 \mathrm{~min}$, and $45 \mathrm{~min}$ in the case of bacteria cultured on LB agar medium) with a Raman spectrometer.

Previously purified cells of $E$. coli and B. subtilis, which were used in experiments showing the influence of bacterial death to their SERS spectrum, were suspended in $10 \mu \mathrm{L}$ of sterile $0.9 \% \mathrm{NaCl}$ solution. Subsequently, they were immediately exposed to specific factor causing death (70\% ethanol, $80^{\circ} \mathrm{C}$, and centrifugation at $13,150 \times g, 100{ }^{\circ} \mathrm{C}$, UV light). Next, the liquid was placed over the SERS substrate and measured after $\sim 5$ min with a Raman spectrometer.

\section{Sample preparation for Raman measurements}

After $24 \mathrm{~h}$ of bacterial cultivation on LB agar medium, about ten single colonies were placed via a sterile plastic inoculating loop into $200 \mu \mathrm{L}$ of sterile $0.9 \% \mathrm{NaCl}$ solution, mixed, and centrifuged for $3 \mathrm{~min}$ at $1070 \times \mathrm{g}$. The centrifugation process in the saline solution was repeated three times to obtain a solution of clean bacterial cells. Purified bacteria were finally suspended in $10 \mu \mathrm{L}$ of sterile $0.9 \% \mathrm{NaCl}$ solution. The mixtures were next placed over the microscopic slides, left for 5 min to dry out, and measured with a Raman spectrometer.

\section{Instrumentation}

\section{Raman and SERS spectroscopy}

Measurements were carried out with a Renishaw inVia Raman system equipped with a 300-mW diode laser-emitting 785$\mathrm{nm}$ line, a 50-mW He-Ne laser-emitting 633-nm line, a 50$\mathrm{mW}$ diode laser-emitting 532-nm line, and a $200-\mathrm{mW} \mathrm{He}-\mathrm{Cd}$ laser-emitting 325-nm line. These lines were used as an excitation source $\left(\lambda_{\mathrm{ex}}\right)$. The light from the lasers was passed through a line filter and focused on a sample mounted on an $\mathrm{X}-\mathrm{Y}-\mathrm{Z}$ translation stage with $\mathrm{a} \times 20$ microscope objective $(\mathrm{NA}=0.25)$. The beam diameter was approximately $5 \mu \mathrm{m}$. The laser power at the sample was $1.5 \mathrm{~mW}, 1 \mathrm{~mW}, 1.2 \mathrm{~mW}$, and $1.6 \mathrm{~mW}$, respectively, for $785-\mathrm{nm}, 633-\mathrm{nm}, 532-\mathrm{nm}$, and 325-nm laser lines. For the 785-nm laser line, the power levels $0.08 \mathrm{~mW}, 0.16 \mathrm{~mW}, 0.8 \mathrm{~mW}, 1.5 \mathrm{~mW}, 8.0 \mathrm{~mW}$, and $16.0 \mathrm{~mW}$ were also tested. The microscope was equipped with three different diffraction gratings (1200 grooves $/ \mathrm{mm}$ [for the 785 $\mathrm{nm}$ line], 1800 grooves $/ \mathrm{mm}$ [for the $633-\mathrm{nm}$ and $532-\mathrm{nm}$ lines], and 2400 grooves $/ \mathrm{mm}$ [for the $325-\mathrm{nm}$ line]), cutoff optical filters, and a $1024 \times 256$-pixel Peltier-cooled
RenCam CCD detector, which allowed registering the Stokes part of Raman spectra with 5-6 $\mathrm{cm}^{-1}$ spectral resolution and $2 \mathrm{~cm}^{-1}$ wavenumber accuracy. The experiments were performed at ambient conditions using a back-scattering geometry.

\section{Scanning electron microscopy}

Observations were performed under high vacuum using the FEI Nova NanoSEM 450. The accelerating voltage was in a range from $2 \mathrm{kV}$ up to $10 \mathrm{kV}$. The wire mesh samples with bacterial species were observed without any additional layer of gold.

\section{SERS substrate preparation}

\section{Ag disc}

Silver SERS substrates were obtained by polishing discs $(\varnothing=$ $10 \mathrm{~mm}, H=5 \mathrm{~mm}$ ) with $\mathrm{Al}_{2} \mathrm{O}_{3}$ slurries in the SII OFL-12 Fiber Polisher (Seiko Instruments). First, slurry contained particles with a size of $0.5 \mathrm{~mm}$, whereas the second one, particles with a size of $0.3 \mathrm{~mm}$. The polishing process was continued until obtaining a mirrored surface of the disc. Next, the discs were washed and sonicated in ultrasonic bath for $10 \mathrm{~min}$ in $70 \%$ ethanol solution. The sonication process was repeated in Millipore water. Subsequently, the discs were electrochemically roughened by oxidation/reduction cycles (ORCs) in the electrochemical cell filled with $0.1 \mathrm{M} \mathrm{KCl}$ solution. The three ORCs were applied $(0.5 \mathrm{~V}$ and -0.5 , both for $40 \mathrm{~s} ; 0.5 \mathrm{~V}$ and -0.5 , both for $15 \mathrm{~s} ; 0.5 \mathrm{~V}$ for $15 \mathrm{~s}$ and -0.5 for $30 \mathrm{~s}$ ). In the last step, the reduction potential of $-0.4 \mathrm{~V}$ was applied for 300 s. Finally, the silver discs were rinsed with Millipore water, dried, and used immediately in SERS experiments. The scanning electron microscopy (SEM) images of the surface of Ag disc are presented in ESM Fig. S2a and in the section "The influence of base material building the SERS substrate."

\section{Silver-coated silicon plate $(\mathrm{Ag} / \mathrm{Si})$}

One-sidedly polished silicone plates $(\varnothing=25 \mathrm{~mm})$ were placed in a beaker filled with $30 \% \mathrm{KOH}$ solution for $40 \mathrm{~min}$ at $50{ }^{\circ} \mathrm{C}$. Next, after rinsing the plates in Millipore water, they were sonicated in ultrasonic bath for $15 \mathrm{~min}$ at $50{ }^{\circ} \mathrm{C}$ in the following substances: acetone, isopropyl alcohol, and Millipore water. Next, the platforms were dried for $30 \mathrm{~min}$ at $50{ }^{\circ} \mathrm{C}$ and placed in a physical vapor deposition (PVD) device and sputtered with a 10-nm layer of silver. The substrates were used immediately after their preparation. The SEM images of the surface of $\mathrm{Ag} / \mathrm{Si}$ substrate are presented in ESM Fig. S2b and in the section "The influence of base material building the SERS substrate." 


\section{Silver-coated steel mesh (Ag/steel)}

In order to obtain a $\mathrm{Ag} /$ steel SERS substrate, a wire mesh sample $(40 \mathrm{~mm} \times 40 \mathrm{~mm})$ was placed in a beaker filled with acetone and sonicated for $10 \mathrm{~min}$ in ultrasonic bath at a temperature of $50{ }^{\circ} \mathrm{C}$. The process was repeated three times: with a new portion of acetone at $50{ }^{\circ} \mathrm{C}$, with isopropyl alcohol at $50^{\circ} \mathrm{C}$, and with Millipore water at ambient temperature. Next, the cleaned wire mesh was dried for $30 \mathrm{~min}$ at $50{ }^{\circ} \mathrm{C}$, placed in a PVD device, and sputtered with a 50-nm layer of $\mathrm{Ag}$ (or of $\mathrm{Au}, \mathrm{Cu}$, or $\mathrm{Ag} / \mathrm{Au}$ alloy). The substrates were used immediately after their preparation. The SEM images of the surface of $\mathrm{Ag} /$ steel substrate are presented in ESM Fig. S2c and in the section "The influence of base material building the SERS substrate."

\section{Collection of the SERS and Raman spectra}

The Raman and SERS spectra of bacterial cells were recorded in mapping mode almost immediately after placing the microscope slide or SERS platform under the microscope lens. Before performing SERS measurements, Raman spectra of pristine SERS substrates were recorded (ESM Fig. S3).

For each sample, 30 spectra were collected; thus, each spectrum presented in this publication is a result of averaged 30 measurements. For all spectra, the laser power was set to $1.5 \mathrm{~mW}$. Next, the spectra were saved and processed with OPUS software, ver. 2012 (Bruker Optik GmbH, Germany). The mentioned program allowed to (i) average the spectra within one map, (ii) remove the background due to baseline correction (selected method: concave rubberband correction; number of interactions $=10$ ), (iii) smooth the final spectrum (Savitzky-Golay filter, 9 points), and (iv) normalize the spectra using min-max normalization; normalization was not applied when differences in absolute spectral intensity among different conditions were evaluated. This applies to the spectra depicted in Fig. 6 and ESM Figs. S7 and S9. The abovementioned bands are crucial for bacterial identification in SERS technique, and the normalization would blur differences in the intensity observed for these bands. The time required for completing a single SERS spectrum was $12 \mathrm{~s}$, whereas for completing a single Raman spectrum, it was $5 \mathrm{~min}$.

\section{Experimental conditions}

The scheme of all experimental conditions is depicted in ESM Fig. S4. In the present work, the following eight experimental conditions (connected with bacterial cultivation, sample preparation, or SERS measurement) were tested:

- Diverse base materials for preparation of SERS substrates (steel mesh, bulk silver, and silicon; ESM Fig. S4a)
- The presence and absence of the SERS substrate (normal Raman vs SERS spectra; ESM Fig. S4b)

- Different SERS-active metals (Ag, $\mathrm{Au}, \mathrm{Ag} / \mathrm{Au}$ alloy, and $\mathrm{Cu}$; ESM Fig. S4c)

- Different laser lines $(532 \mathrm{~nm}, 633 \mathrm{~nm}$, and $785 \mathrm{~nm})$ and laser power levels of $785-\mathrm{nm}$ line $(0.08 \mathrm{~mW}, 0.16 \mathrm{~mW}$, $0.8 \mathrm{~mW}, 1.5 \mathrm{~mW}, 8.0 \mathrm{~mW}$, and $16.0 \mathrm{~mW}$; ESM Fig. S4d)

- Diverse culture media (LB agar, BHI agar, and MEYP agar for cultivation of $B$. subtilis or LB agar, BHI agar, TBX agar, and CCA for cultivation of E. coli; ESM Fig. S4e)

- Duration of bacterial cultivation ( $24 \mathrm{~h}, 48 \mathrm{~h}$, or $72 \mathrm{~h}$; ESM Fig. S4f)

- Influence of bacterial death on their SERS spectra (factors causing cell damage: $70 \%$ ethanol, $-80^{\circ} \mathrm{C}$, centrifugation at $13,150 \times g, 100^{\circ} \mathrm{C}$, UV light; ESM Fig. S4g)

- Time spent by bacterial sample on SERS substrate ( $5 \mathrm{~min}$, $15 \mathrm{~min}$, and $45 \mathrm{~min}$; ESM Fig. S4h).

\section{Results and discussion}

Although numerous reports about Raman and SERS spectroscopy for bacterial imaging are available, there was no attempt to create a uniform SERS protocol for bacterial detection. Therefore, obtaining the similar SERS spectra of particular bacterial species is still a challenging task. The optimization of the conditions and factors influencing SERS, which will lead to the development of uniform, reproducible SERS spectra of bacterial cells, is needed. As SERS is a very sensitive spectroscopic technique, the enhancement of Raman signal should depend on many factors, including the type of SERSactive metal, the frequency of incident light, effective Raman cross section, and the structure of the SERS substrate. The size of metal nanostructures used to produce a SERS substrate is also a crucial issue. The huge differences between the spectra may also result from the different cell culture conditions and measurement parameters. This leads to many ambiguities and to the inability to compare obtained spectra. Such dissimilar spectral images hamper the practical application of SERSbased bacterial identification in many fields of science.

\section{Normal Raman versus SERS}

As mentioned before, although the SERS spectrum resembles the normal Raman spectrum, especially in the case of simple chemical compounds, this is not the rule for complex biological substances and biomolecules. In ESM Fig. S5, the normal Raman spectra of $E$. coli and B. subtilis are compared with their SERS spectra. In can be noticed that the SERS spectra of both bacterial species are of extremely better quality than normal Raman spectra. This is connected with the fact that in 
normal Raman, the high background in the spectrum, which is due to the fluorescence and the emission continuum, completely covers the signal from bacterial cells. This problem is eliminated in SERS experiment, to significant extend, when using appropriate SERS substrates, intended for measurements of biological samples. Another argument behind the growing use of SERS is the fact that in this technique, the trace amounts of the chemical or biological compounds allow to obtain the signal of high quality. Obviously, the sample should be first properly prepared (e.g., filtered and rinsed several times) to avoid the adsorption of unwanted sample components to the SERS substrate. Additionally, the duration of SERS experiment for biological samples is considerably short-in order to obtain a single SERS spectrum of bacteria, the time of $12 \mathrm{~s}$ was sufficient.

In conclusion, SERS allows the detection of very low concentration levels of microorganisms in the sample. It also provides the differentiation and identification of very similar species and strains. The detection of such bacterial cells is ultrasensitive and rapid and requires no extrinsic labeling steps. The huge signal from SERS enhancements, coupled with, i.e., large scattering cross sections of microbial cells, allows to obtain spectra from individual bacterial cells. Moreover, the surface of a bacterial cell consists of a diverse range of biomolecules, almost each of them giving a characteristic Raman spectrum. The mixture of these molecules constitutes the total, unique bacterial SERS signal.

\section{The influence of base material building the SERS substrate}

There are a lot of patents and publications describing different SERS substrates and methods of their production [19, 24-37]. However, not all of the SERS substrates give satisfactory enhancement of Raman signal, especially while measuring biological substances. Here, we performed SERS measurements on different SERS substrates obtained by (i) cyclic voltammetry with a silver disc as a working electrode, (ii) sputtering silver via PVD on chemically etched silicon, and (iii) sputtering silver via PVD on steel mesh (see Fig. 1). The aim of this experiment was to compare substrates with different roughness. Their description and additional SEM images can be found in ESM Fig. S2.

As one can observe in Fig. 2, the SERS spectra obtained with the use of mentioned SERS platforms are very similar within bacterial species (E. coli or B. subtilis) - the locations and intensities of the main bands remain unchanged regardless of the type of used SERS platform. In each SERS spectrum, for both $E$. coli and $B$. subtilis, it is possible to observe bands at around $565 \mathrm{~cm}^{-1}$ (C-S-S-C), $620 \mathrm{~cm}^{-1}$ (phenylalanine), $720 \mathrm{~cm}^{-1}$ (adenine in FAD and NAD), $955 \mathrm{~cm}^{-1}$ (C=C deformation), $1000 \mathrm{~cm}^{-1}$ (phenylalanine), $1090 \mathrm{~cm}^{-1}$ (C-C skeletal and $\mathrm{C}-\mathrm{O}-\mathrm{C}$ stretching from glycosidic link), $1240 \mathrm{~cm}^{-1}$ (amide III), $1330 \mathrm{~cm}^{-1}\left(\mathrm{CH}_{2} /\right.$
$\mathrm{CH}_{3}$ wagging mode in purine bases of nucleic acids), $1450 \mathrm{~cm}^{-1}$ $\left(\mathrm{CH}_{2} / \mathrm{CH}_{3}\right.$ deformation of proteins and lipids), and $1590 \mathrm{~cm}^{-1}$ (phenylalanine, hydroxyproline, tyrosine, etc.) [7].

In conclusion, the method and the type of base material used during SERS substrate production should not result in obtaining totally different SERS spectra of the same bacterial species. The minor differences are probably connected with the size of SERSactive nanostructures and, thus, with the properties of hot spots which can be described as the regions of very strong local field enhancement caused by the surface plasmon resonance. The presence of strong additional bands or absence of the main spectroscopic features of bacteria is a key problem that appears during comparison of the SERS spectra of the same bacterial species presented in different scientific publications, e.g., E. coli [38-44]. This may be connected with the purity of the chemical/physical method used to produce SERS platform. As long as the method does not use numerous chemical compounds which may contaminate SERS substrate, e.g., carbonaceous contamination [45], the obtained SERS spectra of bacterial cells should not change dramatically. The visible changes in relative intensities of the same bands are most probably related with the effect of molecular orientation in relation to the polarization of plasmon excitations in the metal substrate. Of course, other factors, including cell culture conditions and the method of sample preparation, may affect the SERS spectra, but these issues will be discussed later in this work.

\section{The influence of the SERS-active metal used to produce a SERS substrate}

It should be highlighted that taking into account the size of whole pathogenic cells and the distance dependence in SERS effect [46], there is consensus among researchers that the observed bacterial spectroscopic features are dominated mainly by their metabolites and outer cell wall constituents such as membrane proteins, amino acids, lipopolysaccharides, fatty acids, and derivatives of purines [47-49].

In order to observe a SERS signal, the adsorption of the analyzed sample onto SERS substrate is required. The type, shape, and size of nanostructures building the platform affect the surface plasmon resonance giving higher or lower Raman signal enhancement. Moreover, the intensity of SERS signal will be different for small molecules than for single cells composed of thousands of molecules. It is because that a whole cell is too large to occupy a hot spot on the substrate. Hot spots are usually localized in the crevices of the metal nanostructures, and their width should not exceed $\sim 2 \mathrm{~nm}$. Such small gaps can be settled only by single molecules and not by relatively large cells (with the diameter of ca. 1-2 $\mu \mathrm{m}$ ). Therefore, the enhancement factors for these two types of samples would be different.

Although the SERS effect was observed for metals, such as $\mathrm{Li}, \mathrm{Na}, \mathrm{K}, \mathrm{Rb}, \mathrm{Cs}, \mathrm{Al}, \mathrm{Ga}, \mathrm{In}, \mathrm{Pt}, \mathrm{Ag}, \mathrm{Au}, \mathrm{Cu}$, and $\mathrm{Rh}$, and their alloys [50], the strongest SERS enhancements are obtained for 
Fig. 1 SEM images of different SERS substrates and bacterial cells adsorbed to them: Ag disc (a) without and (b) with E. coli cells, chemically etched silicon covered with Ag nanostructures (c) without and (d) with $B$. subtilis cell, and steel mesh covered with Ag nanostructures (e) without and (f) with $E$. coli cells. Pink arrows indicate bacterial cells
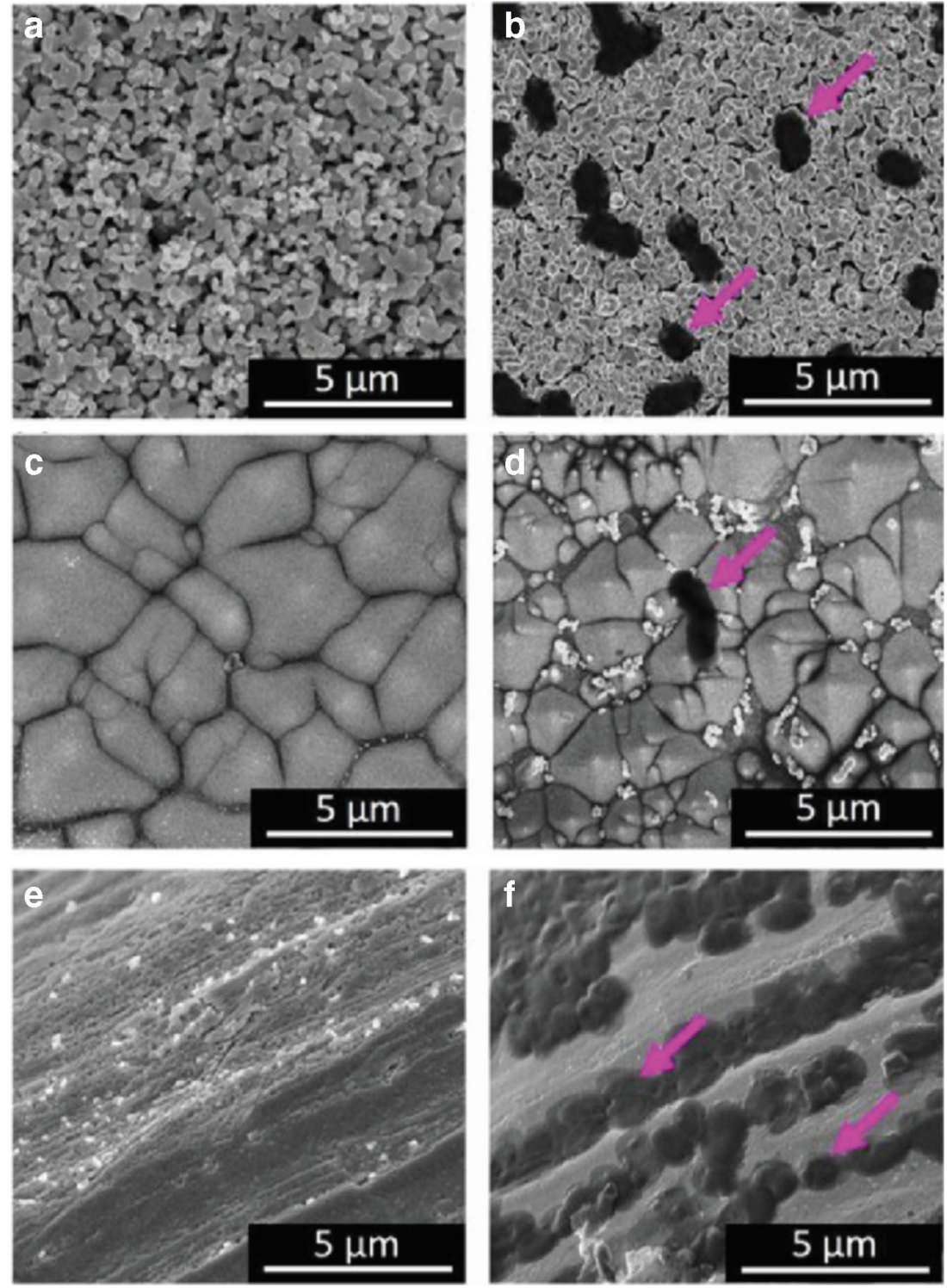

$\mathrm{Ag}, \mathrm{Au}$, and $\mathrm{Cu}$ [51]. For this reason, the SERS measurement of bacteria was performed on four types of SERS substrates composed of steel microwires covered with $\mathrm{Ag}, \mathrm{Au}, \mathrm{Ag}-\mathrm{Au}$ alloy, and $\mathrm{Cu}$ nanostructures. All types of metal-coated steel SERS platforms were prepared in the same way $(50 \mathrm{~nm}$ of appropriate metal was sputtered onto stainless steel wire mesh via PVD and placed in sterile Petri dishes), and therefore, their morphology was expected to be comparable.

As shown in Fig. 3, the highest signal-to-noise ratio (SNR), the most intense SERS bands and therefore, the most characteristic SERS spectra are observed for $\mathrm{Ag} /$ steel and $\mathrm{Au} / \mathrm{Ag} /$ steel platforms, both for E. coli and B. subtilis (Fig. 3a-b, I and II).

The Au/steel platform also shows some characteristic bands, especially at around $1000 \mathrm{~cm}^{-1}, 1330 \mathrm{~cm}^{-1}, 1450 \mathrm{~cm}^{-1}$, and $1590 \mathrm{~cm}^{-1}$ (Fig. 3a, b (III)), but other bands typical for bacterial cells, e.g., at around $620 \mathrm{~cm}^{-1}, 650 \mathrm{~cm}^{-1}, 730 \mathrm{~cm}^{-1}, 960 \mathrm{~cm}^{-1}$, and $1100 \mathrm{~cm}^{-1}$ are absent or hardly noticeable. Additionally, the intensities of observed bands are very low in comparison to $\mathrm{Ag}$ and $\mathrm{Ag}-\mathrm{Au}$ nanostructures. The $\mathrm{Cu}$ substrate, on the contrary, showed only one band, at around $620 \mathrm{~cm}^{-1}$, originating from bacterial cell components of $E$. coli (Fig. 3a (IV)), or showed only four bands at ca. $620 \mathrm{~cm}^{-1}, 780 \mathrm{~cm}^{-1}, 1000 \mathrm{~cm}^{-1}$, and $1450 \mathrm{~cm}^{-1}$ in the case of B. subtilis (Fig. 3b (IV)). As can be concluded, after the comparison of SERS spectra from all considered substrates, the platforms containing silver give the most characteristic and are rich in bands for bacterial spectra.

For further experiments, the substrates consisting of steel mesh covered with Ag nanostructures were chosen. The main reason of selecting this type of SERS substrate was the possibility of observing the biggest difference between $E$. coli and B. subtilis SERS spectra. The second reason is connected with the fact that the $\mathrm{Ag} /$ steel platforms are cheaper to produce than the $\mathrm{Ag} / \mathrm{Au} / \mathrm{steel}$ platforms, and therefore, they are affordable for many laboratories. 
Fig. 2 The averaged SERS spectra of (a) E. coli and (b) B. subtilis measured on (I) $\mathrm{Ag} /$ steel, (II) Ag disc, and (III) $\mathrm{Ag} / \mathrm{Si}$ SERS substrates. Bacteria were cultured on LB agar medium ( $\left.24 \mathrm{~h}, 37^{\circ} \mathrm{C}\right)$. All presented spectra were averaged from 30 SERS measurements performed with the 785-nm laser line $(1.5 \mathrm{~mW})$, baseline corrected, smoothed, and normalized
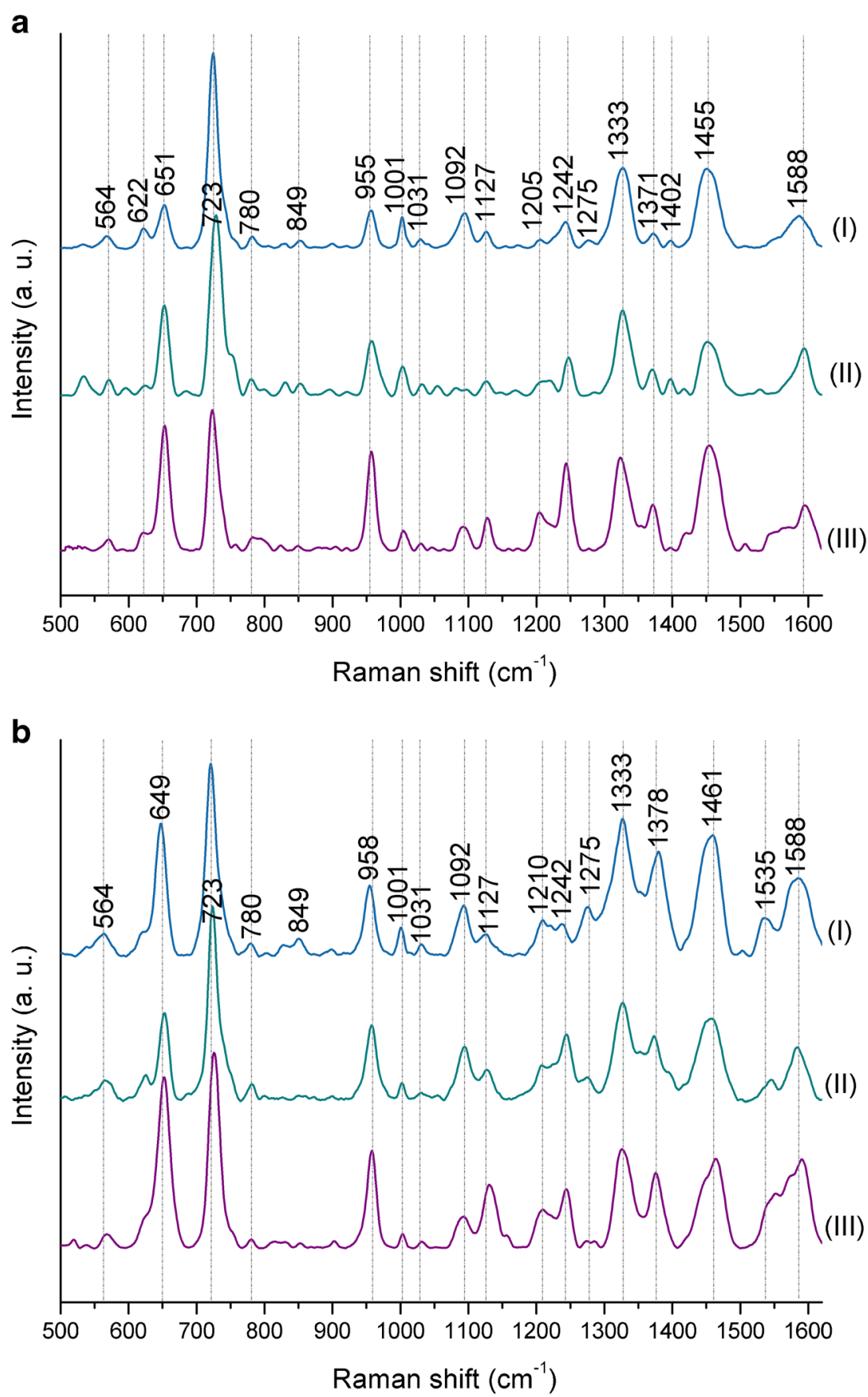

\section{The influence of the laser line wavelength and power}

Several research groups have investigated the SERS spectra of both Gram-positive and Gram-negative bacteria at different wavelengths (for more information, see ESM, section 6). Based on the literature, it can be concluded that in SERS analysis of bacteria, the 633-nm and 785$\mathrm{nm}$ lasers are the most extensively used laser lines. These excitation sources have relatively low photon energy and low fluorescence background and do not cause the photodamage of samples.
The wavelength of the excitation laser and its power on the irradiated sample (power/area) are the crucial factors that affect the high spectral resolution. The spatial resolution is defined by the optics of microscope objective and the wavelength of the laser. In biological studies, the nearinfrared (NIR) lasers at $785 \mathrm{~nm}$ and $830 \mathrm{~nm}$, which have relatively low photon energy and enable the reduction of fluorescence contribution in Raman spectrum, are commonly used.

The results of SERS measurements of E. coli and B. subtilis performed with four different laser lines $(785 \mathrm{~nm}, 633 \mathrm{~nm}$, 
Fig. 3 The SERS spectra of (a) E. coli and (b) B. subtilis measured on steel mesh SERS substrates covered with $50 \mathrm{~nm}$ of (I) $\mathrm{Ag}$, (II) $\mathrm{Ag} / \mathrm{Au}$ alloy, (III) $\mathrm{Au}$, and (IV) $\mathrm{Cu}$. Bacteria were cultured on LB agar medium $\left(24 \mathrm{~h}, 37^{\circ} \mathrm{C}\right)$. All presented spectra were averaged from 30 SERS measurements performed with the 785 -nm laser line $(1.5 \mathrm{~mW})$, baseline corrected, smoothed, and normalized
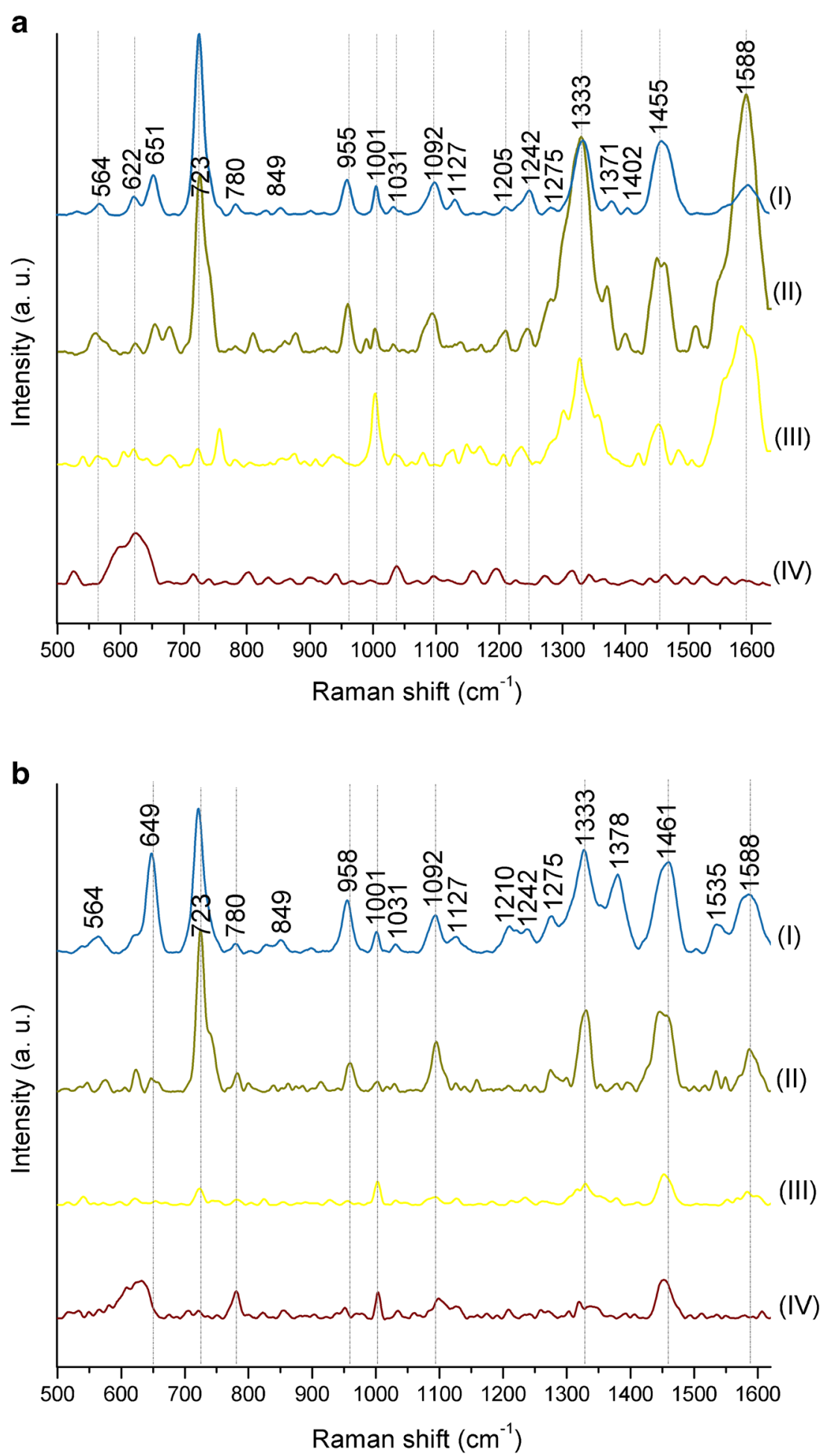

$532 \mathrm{~nm}$, and $325 \mathrm{~nm}$ ) and obtained on steel mesh substrate covered with Ag nanostructures are presented in Fig. 4 (the row, unprocessed spectra are shown in ESM Fig. S6). For all bacterial samples, the same conditions of cell culture $\left(37^{\circ} \mathrm{C}\right.$, $24 \mathrm{~h}$ ) and sample preparation (see sections "Culture media and conditions of bacterial cultivation" and "Sample preparation for SERS measurements") were maintained. The measurements of $E$. coli and B. subtilis performed on the $\mathrm{Ag} /$ steel substrate using 325-nm and 532-nm laser lines resulted in spectra with almost no bands in the case of 325-nm line or with only few bands in the case of 532-nm line (Fig. 4a, b (III and IV)). Furthermore, the spectra obtained with the 532-nm line were difficult to interpret, as the background fluorescence was very high and the background correction 
Fig. 4 The SERS spectra of (a) E. coli and (b) B. subtilis measured with four different laser lines: (I) $785 \mathrm{~nm}$, (II) $633 \mathrm{~nm}$, (III) $532 \mathrm{~nm}$, and (IV) $325 \mathrm{~nm}$. Bacteria were cultured on LB agar medium $\left(24 \mathrm{~h}, 37^{\circ} \mathrm{C}\right)$. All presented spectra were averaged from 30 SERS measurements performed on $\mathrm{Ag} /$ steel mesh SERS substrates, baseline corrected, smoothed, and normalized
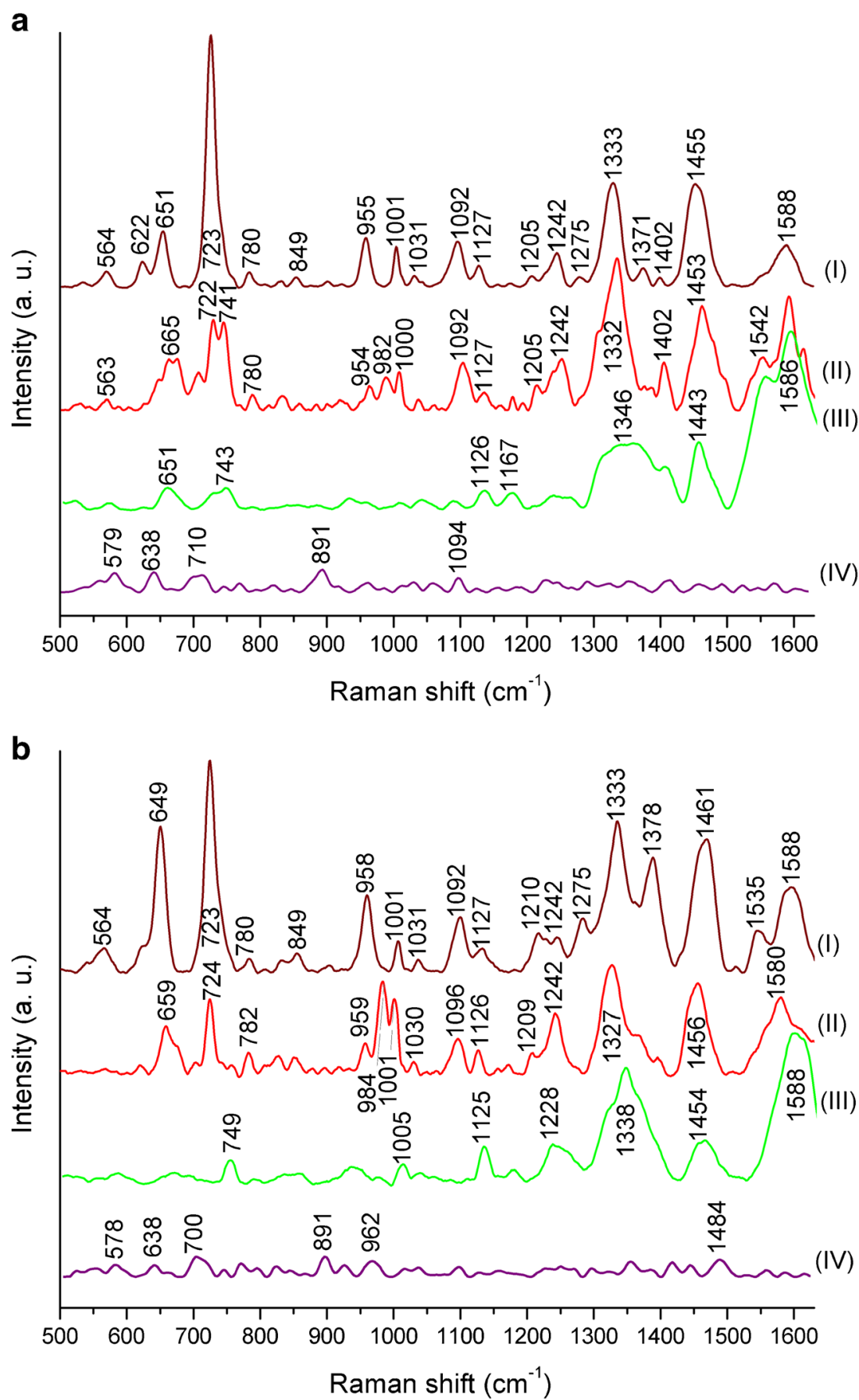

was indispensable. On the contrary, the measurements conducted with 633-nm and 785-nm laser lines (Fig. 4a, b (I and II)) gave the most satisfactory results, as the obtained SERS spectra showed a lot of bands originating from components of bacterial cell. However, after applying the 785-nm laser line, the obtained spectra showed, to some extent, a higher value of SNR than for experiments engaging the 633-nm line (see ESM Fig. S6). Additionally, the intensities of the bands in the spectra obtained with the 785-nm line were higher compared to those in the spectra recorded using the 633-nm line.
The biggest signal enhancement in SERS appears when both surface and resonance effects are combined. The resonance effect is the highest when the $\lambda_{\max }$ of localized surface plasmon resonance (LSPR) is located between $\lambda_{\text {ex }}$ (the exciting wavelength, here at $785 \mathrm{~nm}$ ) and $\lambda_{\text {vib }}$ (the wavelength that is Raman scattered by the analyte, here at $833 \mathrm{~nm}$, corresponding to the band at $731 \mathrm{~cm}^{-1}$ ) [52]. For silver nanostructures, the $\lambda_{\max }$ (the wavelength of maximum extinction) of LSPR is

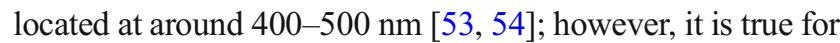
monomeric colloidal suspensions and not necessarily for structures like the ones used in the SERS substrates. It has 
been shown for a number of metals and structures that $\lambda_{\max }$ of LSPR can be tuned over a relatively broad range by changing the spacing and morphology of the noble metal in the array [55-59]. The closer proximity to the region between $\lambda_{\text {ex }}$ and $\lambda_{\text {vib }}$ should result in a greater enhancement. Nonetheless, this piece of information does not explain why the SERS measurements of bacteria performed with the 633-nm laser line are of inferior quality in comparison to the measurements performed with the 785-nm laser line. Recently, this phenomenon has been explained by the existence of plasmonic dark modes, which arise from the plasmon hybridization in a set of interacting NPs [60]. These dark modes have a zero net dipole moment in contrast to dipole-active bright modes and usually do not show up in optical absorption experiments [61]. Moreover, as all absorption measurements are done for metal NPs, it would be precarious to expect that the extinction spectrum obtained from the single metal NPs will be the same as in the case of bulk SERS substrate.

In conclusion, the results presented in Fig. 4 indicate that the laser with $\lambda_{\mathrm{ex}}=785 \mathrm{~nm}$ is the best for investigation of the samples of biological origin. For this reason, all of the following SERS experiments shown in this work were performed using the 785-nm laser line.

The power of laser illuminating the sample depends on the laser spot size and the magnification of the microscope, which results in the intensity of scattered light. The biological samples are generally low scattering materials and very sensitive to the radiation damage and to the local thermal decomposition.

The burning or photodegradation of biological samples, especially over a prolonged period of excitation at a high power of laser, very often results in the presence of the characteristic band in the recorded SERS spectrum at ca. $1500 \mathrm{~cm}^{-1}$ associated with the formation of amorphous carbon. On the other hand, the reduced laser power during measurements results in very poor quality of spectra and generate valueless information.

In ESM Fig. S7, six SERS spectra of E. coli (ESM Fig. S7a) and B. subtilis (ESM Fig. S7b) measured using different laser power levels of the 785-nm laser line are presented. Although all the spectra show bands characteristic for investigated bacteria, in the case of $0.08 \mathrm{~mW}, 0.16 \mathrm{~mW}$, and $0.8 \mathrm{~mW}$ laser power levels, SNR was quite low. This issue was omitted when the measurements were performed with $1.5 \mathrm{~mW}, 8.0 \mathrm{~mW}$, and $16.0 \mathrm{~mW}$ laser power levels. However, when the measurements for $8.0 \mathrm{~mW}$ and $16.0 \mathrm{~mW}$ took more than $1 \mathrm{~min}$ in the same spot of SERS substrate, the band of amorphous carbon appeared in the spectrum. These results indicate that high power of the laser light may cause damage of bacterial cells. For this reason the next SERS measurements were performed using a laser power of $1.5 \mathrm{~mW}$.

The graph of intensity dependence on the laser power for the most prominent SERS band in the spectra of E. coli and B. subtilis is depicted in ESM Fig. S8.

\section{The influence of the type of culture medium}

Media for the cultivation of microorganisms contain the substances, which are necessary to support the growth of microorganisms. It has been already shown that different culture media give different SERS spectra [62]. Slight differences in the composition of specific medium can result in a substantial change in the growth characteristics of microorganisms. The use of different media for the growth of the tested bacteria, E. coli and B. subtilis, affects the diversity of their composition and surface properties. Due to the fact that a SERS technique, as a method of bacterial detection and identification, is based mainly on the investigation of the cell wall and membrane composition, it seems important to examine the impact of diversified bacterial culture media on the obtained SERS results. To study this dependency, we chose the most important and popular growth media available on the market: LB agar and BHI agar for cultivation of both $E$. coli and B. subtilis, MEYP agar for cultivation of B. subtilis, and TBX agar and CCA for cultivation of $E$. coli. The short description of mentioned culture media is given in ESM Table S1.

The graphs presented in Fig. 5 show the results of SERS measurements performed on E. coli and B. subtilis grown on different culture media. The spectra of $E$. coli cultured on LB agar and BHI agar show a very high level of similarity: the band locations and intensities are almost the same. The exceptions from that rule are the bands at around $1330 \mathrm{~cm}^{-1}$ and $1590 \mathrm{~cm}^{-1}$ which exhibit higher intensities in the case of BHI agar than in LB agar. On the contrary, when measuring E. coli cultured on TBX agar and CCA media, one can observe completely different spectroscopic images. The bands at around $620 \mathrm{~cm}^{-1}, 720 \mathrm{~cm}^{-1}, 955 \mathrm{~cm}^{-1}, 1092 \mathrm{~cm}^{-1}$, and $1242 \mathrm{~cm}^{-1}$, which are present for LB agar and BHI agar, are absent for TBX agar and CCA. Additionally, the bacteria grown on TBX agar show extra bands at $600 \mathrm{~cm}^{-1}$, $1173 \mathrm{~cm}^{-1}, 1302 \mathrm{~cm}^{-1}, 1420 \mathrm{~cm}^{-1}$, and $1546 \mathrm{~cm}^{-1}$, while the bacteria from CCA medium exhibit bands at around $600 \mathrm{~cm}^{-1}, 700 \mathrm{~cm}^{-1}, 1118 \mathrm{~cm}^{-1}, 1225 \mathrm{~cm}^{-1}$, and $1290 \mathrm{~cm}^{-1}$. The mentioned bands cannot be assigned to biomolecules building bacterial cell. Their presence is connected with the chromogenic compounds which are released during bacterial growth and cover the SERS signal of bacterial cell. The only bacterial bands which can still be observed are $650 \mathrm{~cm}^{-1}, 1330 \mathrm{~cm}^{-1}, 1450 \mathrm{~cm}^{-1}$, and $1590 \mathrm{~cm}^{-1}$ on TBX agar medium. For CCA medium, the similarity to other spectra is connected only with the band at around $1590 \mathrm{~cm}^{-1}$; however, as this band has much higher intensity in comparison to other spectra, it probably comes from the overlap of two bands: one assigned to bacterial cell and second to chromogenic substrate from CCA medium, as the band at around $1590 \mathrm{~cm}^{-1}$, following different scientific sources, can be assigned to phenylalanine, hydroxyproline, tyrosine, $\mathrm{C}-\mathrm{N}$ stretching, $\mathrm{NH}_{2}$ scissors, $\mathrm{COOH}$ antisymmetric stretching, or ring stretching of adenine/guanine. 
Fig. 5 The SERS spectra of (a) E. coli cultured on (I) LB agar, (II) BHI agar, (III) TBX agar, and (IV) CCA media and (b) B. subtilis cultured on (I) LB agar, (II) BHI agar, and (III) MEYP agar media. Bacteria were cultured for $24 \mathrm{~h}$ in $37^{\circ} \mathrm{C}$. All presented spectra were averaged from 30 SERS measurements performed on $\mathrm{Ag} /$ steel mesh SERS substrates with the $785-\mathrm{nm}$ laser line $(1.5 \mathrm{~mW})$, baseline corrected, smoothed, and normalized
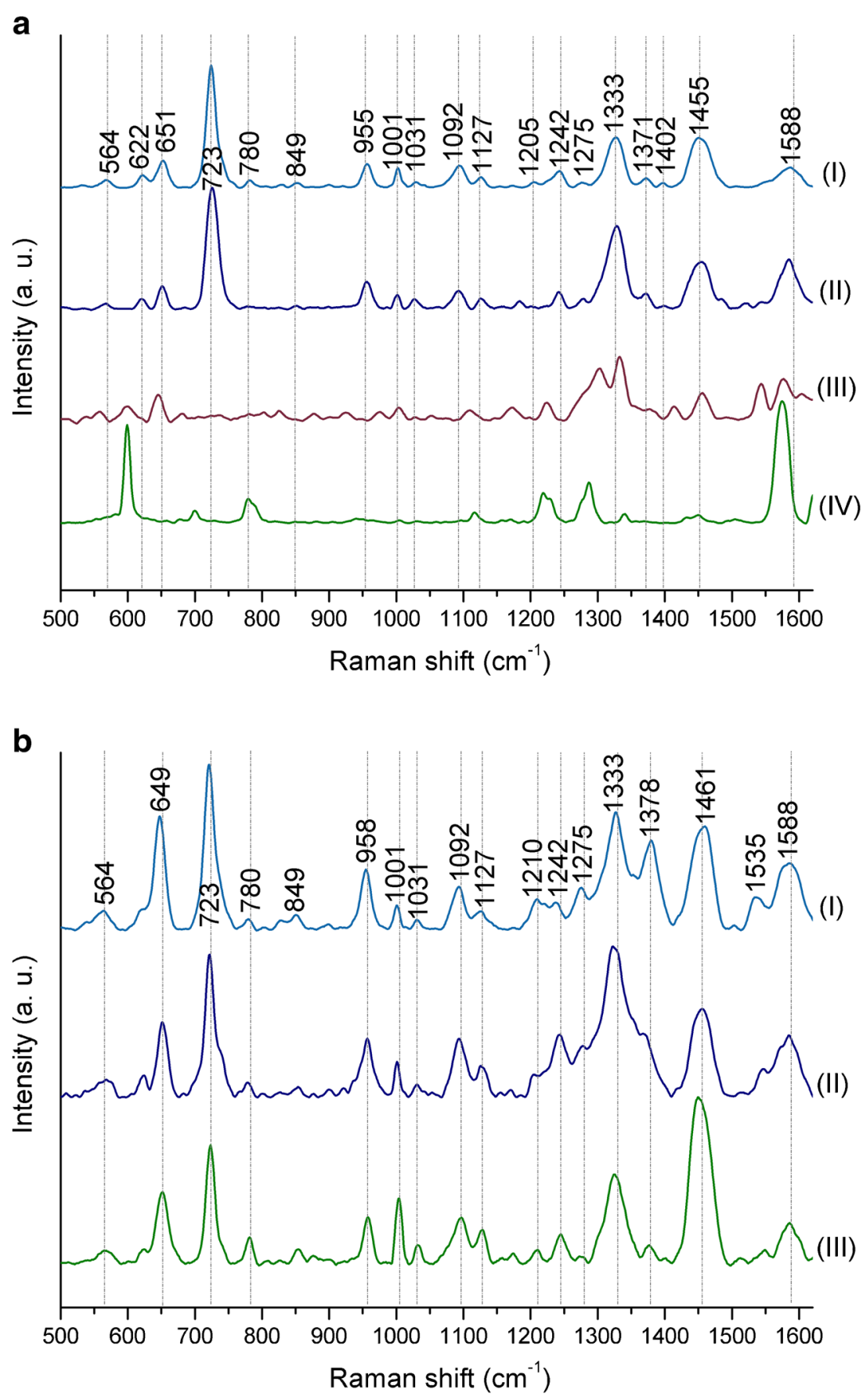

\section{The influence of the time of bacterial culture}

In order to define the cell culture period needed to obtain the most reliable results and the strongest Raman signal enhancement, E. coli and B. subtilis bacteria were cultured for $24 \mathrm{~h}, 48 \mathrm{~h}$, and $72 \mathrm{~h}$, at $37{ }^{\circ} \mathrm{C}$, on the medium frequently used in microbiology, i.e., LB agar. This procedure is necessary, as the cell composition, structure, and amount of produced metabolites may change with time. After these periods, SERS measurements on $\mathrm{Ag}$ substrate were performed.
The results are presented in Fig. 6. As one can notice, after $24 \mathrm{~h}$ and $48 \mathrm{~h}$ of culture period, the majority of SERS bands remained strongly separated from the background for both species. Additionally, on these spectra, almost all band characteristics for bacterial cells could be detected; however, for E. coli after $48 \mathrm{~h}$ of culture (Fig. 6a (II)), one can observe slightly decreased intensity of the band at around $725 \mathrm{~cm}^{-1}$ and increased intensity of the band at around $1330 \mathrm{~cm}^{-1}$. After $72 \mathrm{~h}$ of cell culture of E. coli (Fig. 6a (III)), the intensity of numerous bands dropped down (e.g., at around $780 \mathrm{~cm}^{-1}, 850 \mathrm{~cm}^{-1}, 1030 \mathrm{~cm}^{-1}$, and $1130 \mathrm{~cm}^{-1}$ ), similar to bands at $650 \mathrm{~cm}^{-1}$ and $725 \mathrm{~cm}^{-1}$ in the 
Fig. 6 The SERS spectra of (a) E. coli and (b) B. subtilis after (I) $24 \mathrm{~h}$, (II) $48 \mathrm{~h}$, and (III) $72 \mathrm{~h}$ of culture on LB agar medium $\left(37^{\circ} \mathrm{C}\right)$. All presented spectra were averaged from 30 SERS measurements performed on $\mathrm{Ag} /$ steel mesh SERS substrates with the 785 -nm laser line $(1.5 \mathrm{~mW})$, baseline corrected, and smoothed
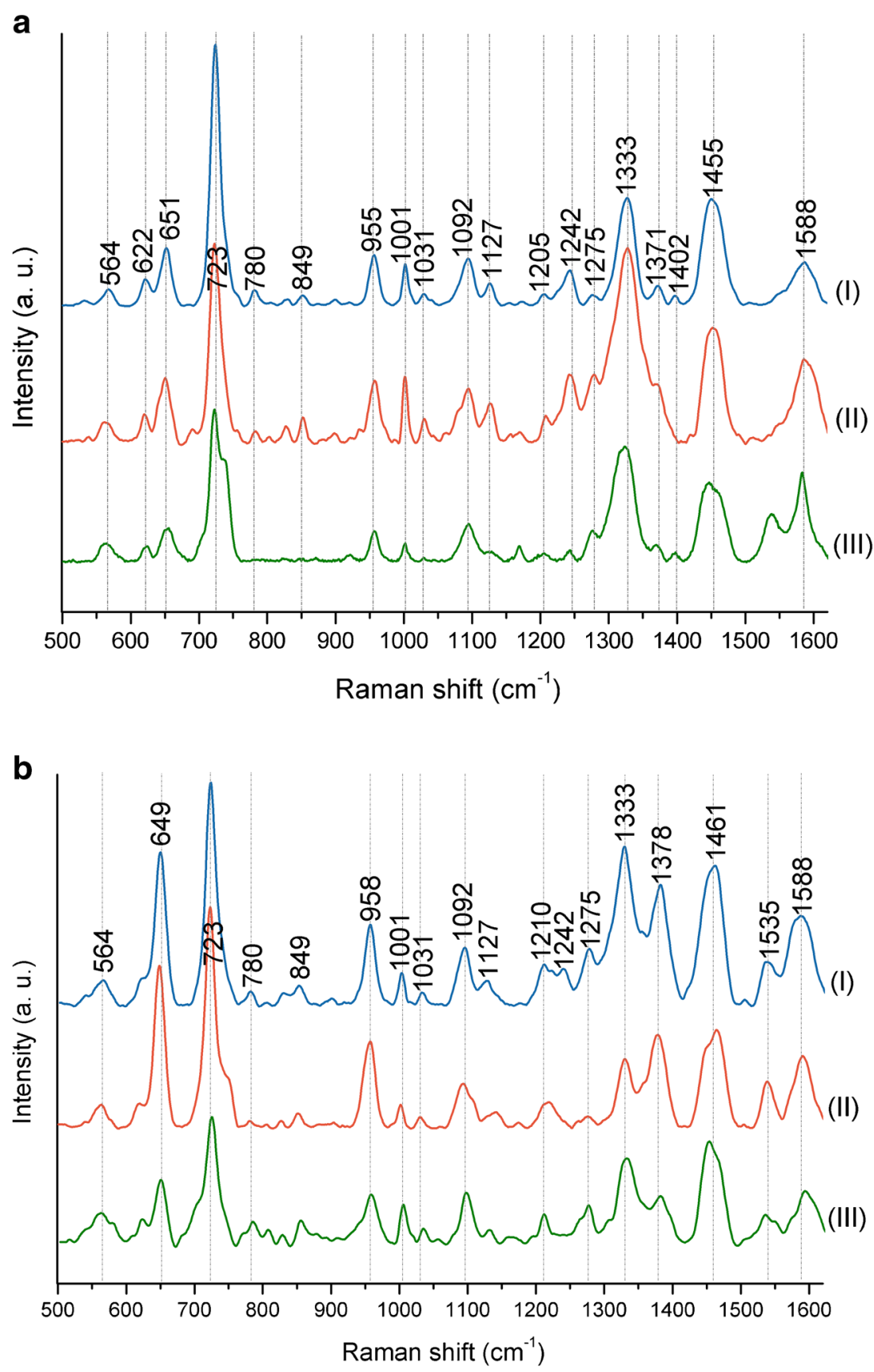

case of B. subtilis (Fig. 6b (III)). These findings are probably connected with the amount of dead bacterial cells which increases with time. As a result of cell death, the integrity of cell wall and cell membrane, which are responsible for the main contribution to the recorded SERS spectrum, decreases. Here, it should also be mentioned that while after $72 \mathrm{~h}$ of cell culture a high number of dead cells might lower the signal intensity, other valuable processes connected with cell death can still be studied by SERS (as long as the conditions are kept consistent within experiments).

For the above reason, it was concluded that bacteria cultured for $24-48 \mathrm{~h}$ are the material giving the appropriate SERS signal intensity and, thus, are suitable for further SERS measurements; however, in order to compare any results, only one cell culture time ( $24 \mathrm{~h}$ or $48 \mathrm{~h}$ ) should be chosen.

\section{Influence of different bacterial treatment conditions}

The easiest and most popular method of killing microbial cells is putting them into contact with ethanol solution [63], preferably $70-85 \%$ aqueous EtOH solution. The presence of water is necessary in order to penetrate the cell wall more completely. As a result, the EtOH solution fills the entire cell, coagulates all proteins, and destroys or inhibits the growth of 
Fig. 7 The SERS spectra of (a) E. coli and (b) B. subtilis after (II) suspending in $70 \%$ ethanol, (III) freezing in $-80{ }^{\circ} \mathrm{C}$, (IV) centrifugation $(13,150 \times g),(\mathbf{V})$ heating up to $100{ }^{\circ} \mathrm{C}$, and (VI) exposition to UV light. The averaged spectrum of bacterial cells from 24 -h culture in $37^{\circ} \mathrm{C}$ (I) was given for comparison. All presented spectra were averaged from 30 SERS measurements performed on $\mathrm{Ag} /$ steel mesh SERS substrates with the 785-nm laser line $(1.5 \mathrm{~mW})$, baseline corrected, smoothed, and normalized
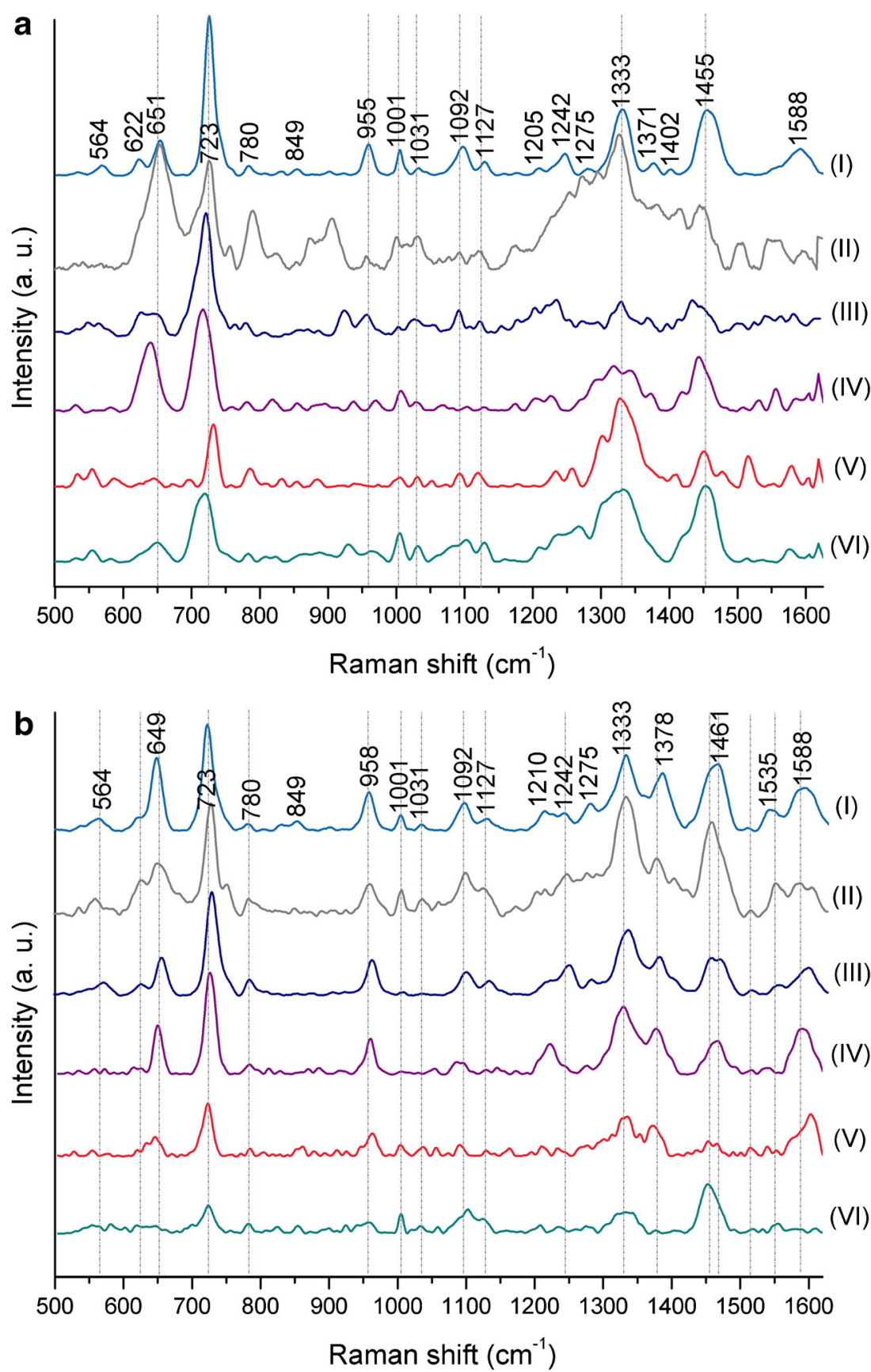

bacteria. Water is also needed to slow evaporation and, thus, to increase surface contact time. The EtOH solution with the concentration $>90 \%$ coagulates proteins immediately and, therefore, causes the formation of a layer which protects other proteins from further coagulation. As one can notice in Fig. 7, the spectra of both $E$. coli and B. subtilis changed a lot after their interaction with alcohol (Fig. 7a, b (II)). Although the main bacterial bands $\left(\sim 650 \mathrm{~cm}^{-1}, 720 \mathrm{~cm}^{-1}, 1330 \mathrm{~cm}^{-1}\right.$, and $1450 \mathrm{~cm}^{-1}$ for both bacterial species and $\sim 960 \mathrm{~cm}^{-1}$, $1000 \mathrm{~cm}^{-1}$, and $1090 \mathrm{~cm}^{-1}$ for B. subtilis) are discernible, the other spectral regions have changed significantly, especially in the case of $E$. coli. What is also worth mentioning is the increase of the band intensity at around $650 \mathrm{~cm}^{-1}$.

In the next step, bacteria were exposed to low temperature $\left(-80{ }^{\circ} \mathrm{C}\right.$; see Fig. 7a, b (III)). Such treatment also causes destruction of microbial cells. This damage is connected with the fact that during the freezing process, the water is converted to ice and solutes accumulate in the residual water. Their high concentration can cause denaturation of biomolecules leading to bacterial death. To avoid the negative effects of freezing, a cryoprotectant such as glycerol is often used [64]. In the present study, bacterial cells were frozen in saline solution, 
without any glycerol added. As in the case of ethanol treatment, the SERS spectrum of $E$. coli has changed a lot-the intensities and shapes of various bands are different in comparison to viable bacterial cells, while the spectroscopic image of $B$. subtilis remains almost the same, with only slight changes in some band intensities.

The similar observations apply to SERS spectra obtained after centrifugation $(13,150 \times g$; Fig. 7a, b (IV)) which has been known to alter bacterial cell surface properties and interior structures, including DNA [65]. It was shown that centrifugation at $15,000 \times g$ causes significant reductions in $E$. coli viability compared to centrifugation at $5000 \times g$, while a minute effect was detected on the viability of Psychrobacter sp. or Staphylococcus epidermidis [66]. It can be concluded that $E$. coli cells are extremely sensitive to centrifugation in contrast to other bacterial species. This can be noticed in SERS spectra: the differences between spectra of viable and strongly centrifuged $E$. coli are clearly discernible (a lot of bands simply disappeared after centrifugation), which is not the case for B. subtilis (the slight differences are limited to the region between 1040 and $1250 \mathrm{~cm}^{-1}$ ).

The high temperature also has bactericidal properties. For this reason, it is used in food production, during pasteurization process. In the case of heating bacterial cells up to $100^{\circ} \mathrm{C}$, the denaturation of all bacterial proteins occurs. These changes can be seen in the SERS spectrum of E. coli and B. subtilis (Fig. 7a, b (V)) - only the bands at $720 \mathrm{~cm}^{-1}$ and $1330 \mathrm{~cm}^{-1}$ are characterized by substantial intensities.

Similar results are obtained for the microbial samples exposed to UV light. It was demonstrated that the 200-280 nm range of UV radiation, called UVC, has germicidal properties [67]. UVC light inactivates microorganisms by damaging
Table 1 Selected culture and measurement conditions

Studied conditions
Normal Raman versus SERS
Base material building the SERS
substrate

SERS-active metal used to produce SERS substrate

Laser line wavelength and power

Type of bacterial culture medium

Duration of bacterial cell cultivation

Additional treatment on bacterial cells

Duration of the measurement

\section{Best selected conditions}

In order to obtain reliable, varied, free-of-noise, and strong background fluorescence spectra of bacterial cell, SERS measurements instead of Raman measurements should be performed

The base material ought to be characterized by high surface roughness and should not give contribution to measured SERS spectrum (it must be fully covered with appropriate SERS-active metal and should not be a good Raman scatterer). As long as these conditions are met, the type of base material used to produce SERS substrate should not significantly affect the obtained SERS spectra

Experiments should be performed on SERS substrates covered with Ag or $\mathrm{Ag} / \mathrm{Au}$ (50:50) nanostructures. The best SERS enhancement was obtained for $\mathrm{Ag}$ and $\mathrm{Ag} / \mathrm{Au}$ alloy. The $\mathrm{Au}$ nanostructures also give SERS enhancement of bacterial cells; however, the signal was weaker compared to $\mathrm{Ag}$ and $\mathrm{Ag} / \mathrm{Au}$ nanostructures

The red laser lines (633 nm and $785 \mathrm{~nm}$ ) gave the lowest background fluorescence and the most characteristic SERS spectra of bacterial cells. The chosen laser power should not cause damage of the sample: for the 785 -nm line, the best laser power was $1.5 \mathrm{~mW}$; however, lower laser power, e.g., $0.80 \mathrm{~mW}$, is also suitable

The culture media should not change the color of the cells (because of the release of chromophore which may give strong contribution to SERS spectrum, covering the signal of bacteria), unless special conditions have to be fulfilled, e.g., the use of chromogenic agars during bacterial detection in food samples, due to International Standardization Organization (ISO) protocols. The best selected media allowing further comparison of SERS spectra of different bacterial species/strains are nonspecific media, e.g., LB agar or BHI agar

The cultivation of bacterial cells should not exceed $48 \mathrm{~h}$. The time of cultivation longer than 2 days may cause the decrease in band intensities in SERS spectra. On the other hand, the minimum time of $24 \mathrm{~h}$ is often needed to obtain perceptible bacterial colonies

No additional treatment should be applied during sample preparation, as it may lead to damage of bacterial cells and, as a result, cause significant changes in their SERS spectra; e.g., the centrifugal force during sample preparation, if needed, should be as low as possible, especially in the case of some bacterial species, e.g., E. coli

Duration of the measurement should be as short as possible (especially for the same spot). Otherwise, the decrease of the band intensity at around $720 \mathrm{~cm}^{-1}$ may be observed 
their DNA due to the dimerization of thymine bases [68]. SERS spectra of bacteria treated with UVC light are shown in Fig. 7a, b (VI). The spectra of both species show bands with decreased intensities at around $720 \mathrm{~cm}^{-1}, 1000 \mathrm{~cm}^{-1}$, $1090 \mathrm{~cm}^{-1}, 1330 \mathrm{~cm}^{-1}$, and $1450 \mathrm{~cm}^{-1}$, while other spectroscopic features are difficult to observe.

The influence of the time spent of bacterial sample on the SERS platform has been also examined, as the toxic effect of SERS substrate covered with Ag NPs may lead to the different spectral response with time. The results of this experiment are presented and described in ESM, section 8. It has been observed that the intensity of significant majority of the bands did not change considerably with time. The one of the few changes was connected with a decrease in intensity of the band at $\sim 720 \mathrm{~cm}^{-1}$ for both investigated bacterial species. The decrease in SERS signal intensity for different spots on the substrate has also been observed, however only after few hours (data not shown). The intention of these experiments was to show that too long exposure of bacterial cells to laser light (even low powered) and Ag NPs may have impact on their spectrum and that the spots on the SERS substrate for which the measurements are done should be changed at least few times during the experiment.

These results indicate that the changes in the intensity of SERS signal of bacteria might be due to their interaction with both SERS substrate and laser light.

\section{Comparison of SERS spectra of E. coli and B. subtilis}

In ESM Fig. S10, we present the SERS spectra of E. coli and $B$. subtilis. The spectra were obtained after applying the best selected culture and measurement conditions (see Table 1), due to previously shown results (Figs. 2, 3, 4, 5, 6, and 7 and ESM Figs. S5, S7, and S9). In order to show the reproducibility of the used technique, the three randomly chosen, unprocessed SERS spectra of $E$. coli and B. subtilis measured on three different $\mathrm{Ag} / \mathrm{steel}$ mesh SERS substrates from three different batches of LB agar medium (culture conditions, $24 \mathrm{~h}$, at $37^{\circ} \mathrm{C}$ ) are depicted in ESM Fig. S11.

\section{Conclusions}

A detailed analysis of the results obtained in this work is an essential step towards understanding the interaction of bacterium with plasmonic nanostructures and to determine which compounds of bacterial cell are visible in the SERS spectrum and why. The obtained results reveal the factors that have a significant impact on the SERS spectra of bacterial cells. This is a very important issue from an analytical, especially qualitative, point of view. These studies progress the current knowledge of biospectroscopy and may start the introduction of SERS-based bacterial cell identification technique as a uniform method of analysis in every field in which detection and identification of bacteria are important. It should be noted that knowledge of bacterial species present in drinking water, air, food and body fluids can be extremely important and, in some cases, may even save human's life, e.g., when the bacteria detected in the sample are pathogenic and can potentially cause death of the consumer/patient. Quick identification would allow for taking a proper action to minimize the risk, e.g., by starting appropriate pharmacological therapy in the case of patients with bacterial infections. The development of this field of science can lead, in the future, to the development of a new and rapid diagnostic method used in hospitals or analytical and microbiological laboratories.

This work can be treated as the protocol for appropriate preparation of SERS experiment of bacteria which may lead to standardization of worldwide obtained results.

Funding information Evelin Witkowska thanks for the financial support from National Science Centre under grant UMO-2016/21/N/ST4/00910.

Agnieszka Kamińska gives thanks for the financial support from Foundation for Polish Science under grant POIR.04.04.00-00-4210/1700 (TEAM TECH/2017-4/23).

\section{Compliance with ethical standards}

Conflict of interest The authors declare that they have no conflict of interests.

Open Access This article is distributed under the terms of the Creative Commons Attribution 4.0 International License (http:// creativecommons.org/licenses/by/4.0/), which permits unrestricted use, distribution, and reproduction in any medium, provided you give appropriate credit to the original author(s) and the source, provide a link to the Creative Commons license, and indicate if changes were made.

Publisher's note Springer Nature remains neutral with regard to jurisdictional claims in published maps and institutional affiliations.

\section{References}

1. Smith E, Dent G. Introduction, basic theory and principles. In: Modern Raman spectroscopy - a practical approach: John Wiley \& Sons, Ltd; 2005. p. 1-21.

2. Idone A, Gulmini M, Henry AI, Casadio F, Chang L, Appolonia L, et al. Silver colloidal pastes for dye analysis of reference and historical textile fibers using direct, extractionless, non-hydrolysis surface-enhanced Raman spectroscopy. Analyst. 2013;138(20):5895903. https://doi.org/10.1039/c3an00788j.

3. Senapati D, Dasary SS, Singh AK, Senapati T, Yu H, Ray PC. A label-free gold-nanoparticle-based SERS assay for direct cyanide detection at the parts-per-trillion level. Chemistry. 2011;17(30): 8445-51. https://doi.org/10.1002/chem.201100617.

4. Inscore F, Shende C, Sengupta A, Huang H, Farquharson S. Detection of drugs of abuse in saliva by surface-enhanced Raman spectroscopy (SERS). Appl Spectrosc. 2011;65(9):1004-8. https:// doi.org/10.1366/11-06310.

5. Sulk RA, Corcoran RC, Carron KT. Surface-enhanced Raman scattering detection of amphetamine and methamphetamine by 
modification with 2-mercaptonicotinic acid. Appl Spectrosc. 1999;53(8):954-9.

6. Dana K, Shende C, Huang H, Farquharson S. Rapid analysis of cocaine in saliva by surface-enhanced Raman spectroscopy. J Anal Bioanal Tech. 2015;6(6):1-5. https://doi.org/10.4172/21559872.1000289.

7. Movasaghi Z, Rehman S, Rehman IU. Raman spectroscopy of biological tissues. Appl Spectrosc Rev. 2007;42(5):493-541. https://doi.org/10.1080/05704920701551530.

8. Schulte F, Joseph V, Panne U, Kneipp J. Applications of Raman and surface-enhanced Raman scattering to the analysis of eukaryotic samples. In: Matousek P, Morris MD, editors. Emerging Raman applications and techniques in biomedical and pharmaceutical fields. Berlin: Springer; 2010. p. 71-95.

9. Bantz KC, Meyer AF, Wittenberg NJ, Im H, Kurtuluș Ö, Lee SH, et al. Recent progress in SERS biosensing. Phys Chem Chem Phys. 2011;13(24):11551-67. https://doi.org/10.1039/c0cp01841d.

10. Henry A-I, Sharma B, Cardinal MF, Kurouski D, Van Duyne RP. Surface-enhanced Raman spectroscopy biosensing: in vivo diagnostics and multimodal imaging. Anal Chem. 2016;88(13):663847. https://doi.org/10.1021/acs.analchem.6b01597.

11. Kneipp K, Wang Y, Kneipp H, Perelman LT, Itzkan I, Dasari RR, et al. Single molecule detection using surface-enhanced Raman scattering (SERS). Phys Rev Lett. 1997;78(9):1667-70.

12. Constantino CJL, Lemma T, Antunes PA, Aroca R. Singlemolecule detection using surface-enhanced resonance Raman scattering and Langmuir-Blodgett monolayers. Anal Chem. 2001;73(15):3674-8. https://doi.org/10.1021/ac0101961.

13. Driskell JD, Zhu Y, Kirkwood CD, Zhao Y, Dluhy RA, Tripp RA. Rapid and sensitive detection of rotavirus molecular signatures using surface enhanced Raman spectroscopy. PLoS One. 2010;5(4):e10222. https://doi.org/10.1371/journal.pone.0010222.

14. Shanmukh S, Jones L, Zhao YP, Driskell JD, Tripp RA, Dluhy RA. Identification and classification of respiratory syncytial virus (RSV) strains by surface-enhanced Raman spectroscopy and multivariate statistical techniques. Anal Bioanal Chem. 2008;390(6):1551-5. https://doi.org/10.1007/s00216-008-1851-0.

15. Witkowska E, Jagielski T, Kaminska A, Kowalska A, HryncewiczGwozdz A, Waluk J. Detection and identification of human fungal pathogens using surface-enhanced Raman spectroscopy and principal component analysis. Anal Methods. 2016;8(48):8427-34. https://doi.org/10.1039/C6AY02957D.

16. Lee S, Chon H, Lee J, Ko J, Chung BH, Lim DW, et al. Rapid and sensitive phenotypic marker detection on breast cancer cells using surface-enhanced Raman scattering (SERS) imaging. Biosens Bioelectron. 2014;51:238-43. https://doi.org/10.1016/j.bios.2013. 07.063 .

17. Pramanik A, Chavva SR, Viraka Nellore BP, May K, Matthew T, Jones S, et al. Development of a SERS probe for selective detection of healthy prostate and malignant prostate cancer cells using ZnII. Chem Asian J. 2017;12(6):665-72. https://doi.org/10.1002/asia. 201601685.

18. Zhang Y, Ye X, Xu G, Jin X, Luan M, Lou J, et al. Identification and distinction of non-small-cell lung cancer cells by intracellular SERS nanoprobes. RSC Adv. 2016;6(7):5401-7. https://doi.org/10.1039/ C5RA21758J.

19. Witkowska E, Szymborski T, Kamińska A, Waluk J. Polymer mat prepared via Forcespinning ${ }^{\mathrm{TM}}$ as a SERS platform for immobilization and detection of bacteria from blood plasma. Mater Sci Eng C. 2017;71:345-50. https://doi.org/10.1016/j.msec.2016.10.027.

20. Kaminska A, Witkowska E, Kowalska A, Skoczynska A, Ronkiewicz P, Szymborski T, et al. Rapid detection and identification of bacterial meningitis pathogens in ex vivo clinical samples by SERS method and principal component analysis. Anal Methods. 2016;8(22):4521-9. https://doi.org/10.1039/ C6AY01018K.
21. Premasiri WR, Moir DT, Klempner MS, Krieger N, Jones G, Ziegler LD. Characterization of the surface enhanced Raman scattering (SERS) of bacteria. J Phys Chem B. 2005;109(1):312-20. https://doi.org/10.1021/jp040442n.

22. Greulich C, Braun D, Peetsch A, Diendorf J, Siebers B, Epple M, et al. The toxic effect of silver ions and silver nanoparticles towards bacteria and human cells occurs in the same concentration range. RSC Adv. 2012;2(17):6981-7. https://doi.org/10.1039/ C2RA20684F.

23. Dakal TC, Kumar A, Majumdar RS, Yadav V. Mechanistic basis of antimicrobial actions of silver nanoparticles. Front Microbiol. 2016;7:1831. https://doi.org/10.3389/fmicb.2016.01831.

24. Fateixa S, Nogueira HIS, Trindade T. Hybrid nanostructures for SERS: materials development and chemical detection. Phys Chem Chem Phys. 2015;17(33):21046-71. https://doi.org/10.1039/ C5CP01032B.

25. Szymborski T, Witkowska E, Adamkiewicz W, Waluk J, Kaminska A. Electrospun polymer mat as a SERS platform for the immobilization and detection of bacteria from fluids. Analyst. 2014;139(20): 5061-4. https://doi.org/10.1039/C4AN01137F.

26. McCord MA, Rooks MJ, editors. SPIE handbook of microlithography, micromachining and microfabrication. Bellingham: SPIE; 2000.

27. Tripp RA, Dluhy RA, Zhao Y. Novel nanostructures for SERS biosensing. Nano Today. 2008;3(3-4):31-7. https://doi.org/10. 1016/S1748-0132(08)70042-2.

28. Colson P, Henrist C, Cloots R. Nanosphere lithography: a powerful method for the controlled manufacturing of nanomaterials. J Nanomater. 2013;2013:19. https://doi.org/10.1155/2013/948510.

29. Zhu C, Meng G, Huang Q, Zhang Z, Xu Q, Liu G, et al. Ag nanosheet-assembled micro-hemispheres as effective SERS substrates. Chem Commun (Camb). 2011;47(9):2709-11. https://doi. org/10.1039/c0cc04482b.

30. Zhang X, Duyne RPV. Optimized silver film over nanosphere surfaces for the biowarfare agent detection based on surface-enhanced Raman spectroscopy. MRS Proc. 2011;876. https://doi.org/10. 1557/PROC-876-R8.54.

31. Siek M, Kaminska A, Kelm A, Rolinski T, Holyst R, Opallo M, et al. Electrodeposition for preparation of efficient surfaceenhanced Raman scattering-active silver nanoparticle substrates for neurotransmitter detection. Electrochim Acta. 2013;89:28491. https://doi.org/10.1016/j.electacta.2012.11.037.

32. Wang XA, Kong X. Review of recent progress of plasmonic materials and nano-structures for surface-enhanced Raman scattering. Materials (Basel). 2015;8(6). https://doi.org/10.3390/ma8063024.

33. Zhao S, Guo Y, Song S, Choi D, Hahm J-i. Application of welldefined indium tin oxide nanorods as Raman active platforms. App Phys Lett. 2012;101(5):053117. https://doi.org/10.1063/1. 4740273.

34. Celik M, Altuntas S, Buyukserin F. Fabrication of nanocraterdecorated anodic aluminum oxide membranes as substrates for reproducibly enhanced SERS signals. Sensors Actuators B Chem. 2018;255:2871-7. https://doi.org/10.1016/j.snb.2017.09.105.

35. Chen Y-C, Hsu J-H, Hsu Y-K. Branched silver nanowires on fluorinedoped tin oxide glass for simultaneous amperometric detection of $\mathrm{H}_{2} \mathrm{O}_{2}$ and of 4-aminothiophenol by SERS. Microchim Acta. 2018;185(2): 106. https://doi.org/10.1007/s00604-017-2625-1.

36. Kandjani AE, Mohammadtaheri M, Thakkar A, Bhargava SK, Bansal V. Zinc oxide/silver nanoarrays as reusable SERS substrates with controllable 'hot-spots' for highly reproducible molecular sensing. J Colloid Interface Sci. 2014;436:251-7. https://doi.org/ 10.1016/j.jcis.2014.09.017.

37. Williamson TL, Guo X, Zukoski A, Sood A, Díaz DJ, Bohn PW. Porous $\mathrm{GaN}$ as a template to produce surface-enhanced Raman scattering-active surfaces. J Phys Chem B. 2005;109(43):2018691. https://doi.org/10.1021/jp0534939. 
38. Liu Y, Chao K, Kim MS, Nou X, editors. Rapid screening and species identification of E. coli, Listeria, and Salmonella by SERS technique. Orlando: SPIE; 2008.

39. Liu T-Y, Tsai K-T, Wang H-H, Chen Y, Chen Y-H, Chao Y-C, et al. Functionalized arrays of Raman-enhancing nanoparticles for capture and culture-free analysis of bacteria in human blood. Nat Commun. 2011;2:538. https://doi.org/10.1038/ncomms1546.

40. Fan C, Hu Z, Mustapha A, Lin M. Rapid detection of food- and waterborne bacteria using surface-enhanced Raman spectroscopy coupled with silver nanosubstrates. Appl Microbiol Biotechnol. 2011;92(5):1053-61. https://doi.org/10.1007/s00253-011-3634-3.

41. Malvadkar N, Kao P, Wang H, Allara DL, Demirel MCASERS. Substrate for detection of E.coli on nanostructured poly(pxylylene). In: Laudon M, Romanowicz B, editors. Nanotechnology 2008: life sciences, medicine \& bio materialstechnical proceedings of the 2008 NSTI nanotechnology conference and trade show: NSTI Nanotech; 2008. p. 555-7.

42. Mircescu NE, Zhou H, Leopold N, Chis V, Ivleva NP, Niessner R, et al. Towards a receptor-free immobilization and SERS detection of urinary tract infections causative pathogens. Anal Bioanal Chem. 2014;406(13):3051-8. https://doi.org/10.1007/s00216-014-7761-4.

43. Chen J, Wu X, Huang Y-w, Zhao Y. Detection of E. coli using SERS active filters with silver nanorod array. Sens Actuators B Chem. 2014;191:485-90. https://doi.org/10.1016/j.snb.2013.10. 038.

44. Su L, Zhang P, Zheng D-w, Wang Y-j-q, Zhong R-g. Rapid detection of Escherichia coli and Salmonella typhimurium by surfaceenhanced Raman scattering. Optoelectron Lett. 2015;11(2):157-60. https://doi.org/10.1007/s11801-015-4216-x.

45. Norrod KL, Rowlen KL. Removal of carbonaceous contamination from SERS-active silver by self-assembly of decanethiol. Anal Chem. 1998;70(19):4218-21. https://doi.org/10.1021/ac980114h.

46. Kovacs GJ, Loutfy RO, Vincett PS, Jennings C, Aroca R. Distance dependence of SERS enhancement factor from Langmuir-Blodgett monolayers on metal island films: evidence for the electromagnetic mechanism. Langmuir. 1986;2(6):689-94. https://doi.org/10.1021/ la00072a001.

47. Felix-Rivera H, Gonzalez R, Rodriguez GDM, Primera-Pedrozo OM, Rios-Velazquez C, Hernandez-Rivera SP. Improving SERS detection of Bacillus thuringiensis using silver nanoparticles reduced with hydroxylamine and with citrate capped borohydride. Int J Spectrosc. 2011;2011:9. https://doi.org/10.1155/2011/989504.

48. Çulha M, Yazici MM, Kahraman M, Sahin F, Kocagöz S. Surfaceenhanced Raman scattering of Bacteria in microwells constructed from silver nanoparticles. J Nanotechnol. 2012;2012:7. https://doi. org/10.1155/2012/297560.

49. Sivanesan A, Witkowska E, Adamkiewicz W, Dziewit L, Kaminska A, Waluk J. Nanostructured silver-gold bimetallic SERS substrates for selective identification of bacteria in human blood. Analyst. 2014;139(5):1037-43. https://doi.org/10.1039/c3an01924a.

50. Duyne RPV, Hulteen JC, Treichel DA. Atomic force microscopy and surface-enhanced Raman spectroscopy. I. Ag island films and Ag film over polymer nanosphere surfaces supported on glass. J Chem Phys. 1993;99(3):2101-15. https://doi.org/10.1063/1. 465276.

51. Tian Z-Q, Yang Z-L, Ren B, Wu D-Y. SERS from transition metals and excited by ultraviolet light. In: Kneipp K, Moskovits M, Kneipp H, editors. Surface-enhanced Raman scattering: physics and applications. Berlin: Springer; 2006. p. 125-46.

52. McFarland AD, Young MA, Dieringer JA, Van Duyne RP. Wavelength-scanned surface-enhanced Raman excitation spectroscopy. J Phys Chem B. 2005;109(22):11279-85. https://doi.org/10. 1021/jp050508u.
53. Shrivas K, Sahu S, Patra GK, Jaiswal NK, Shankar R. Localized surface plasmon resonance of silver nanoparticles for sensitive colorimetric detection of chromium in surface water, industrial waste water and vegetable samples. Anal Methods. 2016;8(9):2088-96. https://doi.org/10.1039/C5AY03120F.

54. Oldenburg SJ. https://www.sigmaaldrich.com/technicaldocuments/articles/materials-science/nanomaterials/silvernanoparticles.html. Accessed 10 Dec 2018.

55. Zhao L, Kelly KL, Schatz GC. The extinction spectra of silver nanoparticle arrays: influence of array structure on plasmon resonance wavelength and width. J Phys Chem B. 2003;107(30):734350. https://doi.org/10.1021/jp034235j.

56. Kanipe KN, Chidester PPF, Stucky GD, Moskovits M. Large format surface-enhanced Raman spectroscopy substrate optimized for enhancement and uniformity. ACS Nano. 2016;10(8):7566-71. https://doi.org/10.1021/acsnano.6b02564.

57. Jiao Y, Ryckman JD, Koktysh DS, Weiss SM. Controlling surface enhanced Raman scattering using grating-type patterned nanoporous gold substrates. Opt Mater Express. 2013;3(8):113748. https://doi.org/10.1364/OME.3.001137.

58. Kurouski D, Large N, Chiang N, Henry A-I, Seideman T, Schatz $\mathrm{GC}$, et al. Unraveling the near- and far-field relationship of 2D surface-enhanced Raman spectroscopy substrates using wavelength-scan surface-enhanced Raman excitation spectroscopy. J Phys Chem C. 2017;121(27):14737-44. https://doi.org/10.1021/ acs.jpcc.7b04787.

59. Banholzer MJ, Millstone JE, Qin L, Mirkin CA. Rationally designed nanostructures for surface-enhanced Raman spectroscopy. Chem Soc Rev. 2008;37(5):885-97. https://doi.org/10.1039/ B710915F.

60. Gómez DE, Teo ZQ, Altissimo M, Davis TJ, Earl S, Roberts A. The dark side of plasmonics. Nano Lett. 2013;13(8):3722-8. https://doi. org/10.1021/nl401656e.

61. Kneipp K, Kneipp H, Kneipp J. Probing plasmonic nanostructures by photons and electrons. Chem Sci. 2015;6(5):2721-6. https://doi. org/10.1039/c4sc03508a.

62. Marotta NE, Bottomley LA. Surface-enhanced Raman scattering of bacterial cell culture growth media. Appl Spectrosc. 2010;64(6): 601-6. https://doi.org/10.1366/000370210791414326.

63. Kampf G, Hollingsworth A. Comprehensive bactericidal activity of an ethanol-based hand gel in 15 seconds. Ann Clin Microbiol Antimicrob. 2008;7:2. https://doi.org/10.1186/1476-0711-7-2.

64. Oskouei DD, Bekmen N, Ellidokuz H, Y1lmaz Ö. Evaluation of different cryoprotective agents in maintenance of viability of Helicobacter pylori in stock culture media. Braz J Microbiol. 2010;41(4):1038-46. https://doi.org/10.1590/S1517838220100004000023 .

65. Peterson BW, Sharma PK, van der Mei HC, Busscher HJ. Bacterial cell surface damage due to centrifugal compaction. Appl Environ Microbiol. 2012;78(1):120-5.

66. Pembrey RS, Marshall KC, Schneider RP. Cell surface analysis techniques: what do cell preparation protocols do to cell surface properties? Appl Environ Microbiol. 1999;65(7):2877-94.

67. Takada A, Matsushita K, Horioka S, Furuichi Y, Sumi Y. Bactericidal effects of $310 \mathrm{~nm}$ ultraviolet light-emitting diode irradiation on oral bacteria. BMC Oral Health. 2017;17:96. https://doi. org/10.1186/s12903-017-0382-5.

68. Galli L, Brusa V, Rodríguez R, Signorini M, Oteiza JM, Leotta GA. Escherichia coli in food products. In: Torres AG, editor. Escherichia coli in the Americas. Cham: Springer International; 2016. p. 173-203. 